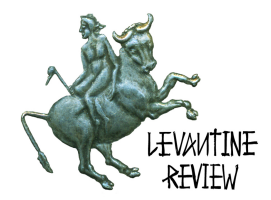

\title{
SHARING SACRED SPACES IN THE MEDITERRANEAN: CHRISTIANS, MUSLIMS, AND JEWS AT SHRINES AND SANCTUARIES.
}

\author{
William Gourlay*
}

Sharing Sacred Spaces in the Mediterranean: Christians, Muslims and Jews at Shrines and Sanctuaries. By Dionigi Albera and Maria Couroucli (editors), Indiana University Press, 2012, Cloth, 288 pp. \$70.00 ISBN 9780253356338

Good fences make good neighbors, the old adage tells us, but on the other hand sharing and interacting with one's neighbors, rather than excluding them, are activities that contribute to the essence of neighborliness. Turkey's Foreign Minister Ahmet Davutoğlu has received equal parts commendation and ridicule for his adopted policy of "zero problems with neighbors," and it can hardly be claimed that the neighborhood of the eastern Mediterranean is a happy one at present. Popular consensus would have it that the Levant is a region of unbridgeable divides and polarised communities, antagonistic to and incompatible with each other due to hardwired intolerance and enduring "ancient hatreds." Proponents of such a contention can point to a litany of events within living memory-enduring hostilities between Israelis and Palestinians, the Lebanese Civil War, the Yugoslav wars of the 1990s, conflicts arising out of the Arab Spring-and claim "it was ever thus."

Certain Western pundits may cast an Orientalist perspective on intercommunal strife in the Levant-such events would never happen in the "secular," "civilised," "advanced" West, they may claim-but it is an irony that the source of much of the strife is the pursuit of homogeneity-uniformity of language, religion and identity-that is a hallmark of the nation-state, an idea imported wholesale from the West. This irony is compounded by the fact that interethnic discord can only arise in the first place because indigenous ethnoreligious diversity_-something that has been largely eradicated in the West-is still a reality in the Levant.

Yet for all of the strife at the macro geo-political level that attracts the media spotlight, it is still the case that at a personal level intercommunal interaction occurs on a daily basis in the Levant. And for all the nation-building projects during the last century that were intent on molding and clearly demarcating traditions and distinct nations along ethnoreligious lines, boundaries remain blurred and there remain overlaps where rituals, customs, religious practices and sacred sites are shared between different communities. Indeed, devotional practices, generally regarded as the starkest definitional markers separating communities, often provide the spaces that best allow intercommunal and interfaith contact. Sharing Sacred Spaces in the Mediterranean: Christians, Muslims and 


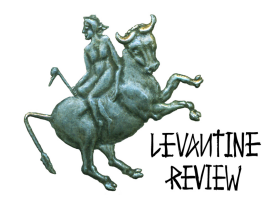

Jews at Shrines and Sanctuaries, a collection edited by Albera Dionigi and Maria Couroucli, brings together a comparative anthropology of these practices and spaces, examining from historical and ethnographic viewpoints the wheres and hows of intercommunal sharing from the Balkans, Turkey, Morocco, Egypt and Syria.

Maria Couroucli, in her introduction to the volume, highlights the long-standing multiconfessional nature of the political entities of the eastern Mediterranean. The Byzantine and Ottoman empires were culturally much more diverse than the states of Western Europe, which, from the time of the Catholic Reconquista beginning in Spain in the Middle Ages, saw a monoculture premised on uniformity of language, religion, identity as the essential foundation of the nation-state. By the mid-nineteenth century, the Ottoman Empire, too, began to fragment as the appeal of this Western European model spread amongst diverse communities now keen to throw off the Ottoman "yoke" and determine their own individual, national trajectories. Ethnicity and religion had constituted important social markers during the Ottoman era, but try as they might new nationalist elites could not deny or completely eradicate long-standing modes of cohabitation or relationships that spanned religious and ethnic divides. Sharing of sacred spaces and rituals tended to happen, even during the less nationalistically oriented Ottoman era, on the peripheries, away from the control of central authorities. Thus, as Couroucli points out, traditional practices of mixing and sharing weren't a result of government-imposed multicultural policies as may be the case in Western societies but were the result of the mechanisms and organic nature of everyday life (p5). To that end, the practices, events, customs and rituals that are the subjects of this book do not conform to a single habitus. Informed by a multitude of political circumstances, environmental and societal contexts, and doctrinal constraints, they are as diverse as they are complex.

Such circumstances demand the "thick description" favored by Clifford Geertz, the close observation and detailed analysis of practice, circumstance and location. Accordingly, Glenn Bowman argues, in his study of shared shrines in West Bank Palestine and western Macedonia, that to truly understand the nature of "sharing" in this context it is "vital to attend to who is saying what to whom and who is listening" (p13). Not only that, but observing shared practices as they are occurring is necessary, as opposed to afterthe-fact interpretation, once communities have fallen into conflict and intercommunal mixing is no longer a reality. Bowman observes Muslim and Christian interaction at several sites in Bethlehem and Jerusalem and in Macedonia. He focuses on questions of power and resistance, and how these notions may shift given different political and societal contexts. At the West Bank shrine of Bir es-Saiyideh (The Well of the Virgin Mary in Beit Sahhour,) during the Palestinian intifada, Muslim and Christian identities were subsumed to a national Palestinian identity in response to Israeli aggression: solidarity was catalyzed, and sharing enhanced, by an external threat. At three different sites in Macedonia, Bowman details three distinct models of interaction: shared practice at the well of an Orthodox monastery, mixed practice, and "antagonistic tolerance" (p17). In each of these, again, Bowman observes that questions of power and resistance are significant factors affecting interactions, and he draws a conclusion that separation 


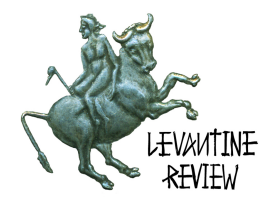

and antagonism may come to replace mixing and sharing as resurgent nationalism seeks to promote unity and exclusion over syncretic activities (p26).

Gilles de Rapper's discussion of the notion of the vakëf in Albania explores an entirely different set of socio-political circumstances, religion having been banned there from 1967 until 1990. Originally from the Turkish vaklf, meaning a religious foundation established for charitable purposes, vakëf has come to describe any popularly designated "holy place" (vend e shentjë, p33). Distinct from churches and mosques, vakëfe are describes as being "for all religions" (p30): by way of explanation Rapper is told at the feast of St John at Voskopojë, "We all came from the same mud; worshipping God is what matters" (p46), elsewhere that "Here people have to respect one another" (p40). Nonetheless, it is clear that power relationships are still at work: the Christians at Voskopojë are keen to point out that Muslims visit Orthodox holy places largely because their presence implies the superiority of the Christian creed. Rapper investigates the gradual shift in definition of the term vakëf, concluding that the atheism imposed by the Albanian regime likely contributed to the Albanian penchant for visiting vakëfe. The Communists' top-down approach could not stamp out the spirituality of the Albanians, who chose to visit sites whose confessional nature was less clearly defined than that of a church or mosque (p47).

Top-down control has had an impact on the practice of religion in Turkey, too. While being Western aligned, and boasting a political "model" that is theoretically applicable to the rest of the Muslim world, the Turkish government has kept a tight rein on religious practice. The Ottoman Empire that preceded the modern Turkish Republic was distinctive for its multiconfessional polyphony, but religious diversity has declined dramatically in the last century. In this volume Dionigi Albera and Benoît Fliche contribute what they describe as a "preliminary study" of interfaith crossovers in Istanbul (p97). Undertaking research at a time of heightened tensions for non-Muslim minorities in Turkey, Albera and Fliche nonetheless observe an array of devotional overlaps and "inventive" (p114) behaviours in the great Turkish metropolis, noting that while some sites of interfaith activities may be becoming less frequented others are becoming popular, with some even becoming "fashionable" amongst Turks of all stripes (p98-9). The bulk of this chapter focuses on religious practices at the church dedicated to St Anthony of Padua, in the bustling heart of the Beyoğlu neighbourhood. Here, the authors record some truly remarkable practices, not least the sharing of offertory bread in a "paraphrase of the Eucharist" (p111) and a telling scene where a female visitor first admonishes an over-efficient church attendant who has extinguished devotional candles lit by Muslim worshippers then relights the candles (p109).

One of the instances of intercommunal mixing that Albera and Fliche note as being "fashionable" is the celebration of St George's Day on the island of Büyükada (Prinkipo) off the coast of Istanbul. Maria Couroucli's chapter focuses on this particular event, both at this location, once a redoubt of Istanbul's non-Muslim bourgeoisie and now frequented by Turkey's modern elites (pp124-6), as well as probing veneration of St George in its broader implications across Anatolia (pp130-1). Further, Couroucli documents a profound latticework of links between St George the dragon slayer in 


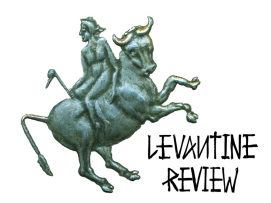

Christian guise and an array of figures, historical and legendary, across the eastern Mediterranean, from Alexander the Great, Digenis Akrites, the Byzantine hero, and in turn Persian legends and The Arabian Nights (pp132-4). As a "permanent outsider, he is at home in frontier spaces, in the interstices" (p135).

As in Albania and to an extent in Turkey, state policy was intended to engineer a modern society in Yugoslavia. Here, Titoist exhortations to "brotherhood and unity" were pervasive, an attempt to forge a common identity and dispel individual nationalistic impulses. The internecine war of 1990s Bosnia made such rhetoric look like so much wishful thinking. Bojan Baskar's contribution to this collection considers the tradition of komšiluk (from the Turkish komşuluk: neighborliness), the everyday relationships of different peoples living at close quarters, as manifestation of an ofttheorised Bosnian tradition of syncretism. In a region of such intense, recent acrimony, the very existence of komšiluk is contested by some nationalist-informed voices, but Baskar points out that traditions of taking care of neighbors' shrines and, during the wars of the 1990s, instances of members of one faith protecting and saving those of a different faith are well documented and widespread (pp56-7). He examines the legacy of the Ottoman millet system (p61), the alleged adoption of Islam by the Bosnian nobility (p59) and the rural practice of moba (inter-communal co-operation on agricultural and building projects, p58) and the implications they may have on traditions of syncretism in Bosnia. Ultimately, Baskar stresses that this is a subject where much has been recorded and described but there is still much analysis to be done (p 67).

Galina Valtchinova, too, investigates komşuluk, as an "ethic of togetherness", at the Krastova Gora (Mount of the Cross), in a region of historical upheavals on the Bulgarian border that has seen redrawing of national and religious boundaries. Valtchinova is at pains to point out that for all the implicit rules and attitudes concerning living side by side that are at the heart of komşuluk, it is also a means of maintaining distinct identities and distances between groups (p77). At the heart of Valtchinova's chapter is the consideration of whether cases of religious mixing should be seen as intrinsic to specific locations and religious landscapes or whether they should be seen as passing phases that are shaped by diverse contexts and circumstances (p69). At Krastova Gora, in the early 1990s, in the flush of freedom of religion after Communist rule ended, intercommunal mixing was widespread, local Muslim Pomaks mingling freely with Orthodox Christians, however, over time an institutionalization of the site was observed, such that commingling gradually waned, Muslim Pomaks now visiting a nearby türbe, and Orthodox pilgrims expected to conform to more rigidly defined devotional practices (pp84-6).

Henk Driessen's short chapter is the only one to examine mixing outside the former Ottoman realm, and is the only account that details instances of Jewish-Muslim interaction. In the Rif Mountains of northern Morocco, Muslims have long visited the site of the shrine to a local Jewish holy man, Rabbi Saadia Datsi, who, according to legend, fled from Catholic Spain in the 1490s. In fact, this is only one of around one hundred "double shrines" visited by both Jews and Muslims as recorded in the 1940s by 


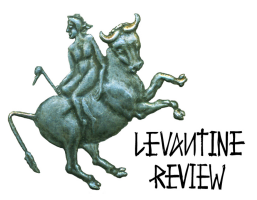

the French ethnographer L. Voinot (p142). Driessen points out that the sharing of a tradition of pilgrimage to the holy man's tomb did not automatically mean equality between the communities of the Rif. A strict hierarchical system was in place, with Jews subordinate to the dominant Muslim Berbers (p144). As recorded elsewhere in this volume, geo-political changes, in this case the Arab-Israeli war of 1967 and Jewish emigration, have effectively brought an end to this shared tradition.

The transformation of Egyptian politics and society have also brought changes to that country's long tradition of intercommunal shrine visitation, such that, as Catherine Mayeur-Jaouen argues, what was once a multiconfessional society is now biconfessional (p148), comprised of a Muslim majority and a Coptic minority. Egypt has experienced a rise in confessional tensions, particularly since the $1980 \mathrm{~s}$, such that even the skyline is a source of competition, with Muslim and Coptic communities seeking to outdo one another building taller minarets and church towers, respectively (p166). Competing confessional visions have fed off each other and to a degree emulated each other: the hardening of Islamic leaders' rhetoric has been matched by the same from Coptic leaders. Indeed Mayeur-Jaouen points out the imposition of a "religious correctness" (p169), as clerical control extends over previously community-based practices and rituals. She tells of the Tree of the Virgin in Matarieh, once venerated by Muslims and Copts, which has been transformed from a freely accessible "shrine" to a "museum" surrounded by a fence. Visitors now must buy tickets and cannot physically touch the tree (p159). Mayeur-Jaouen does not lay all the blame for the loss of interconfessional mixing on imposed religious orthodoxy, but also points to changes in rural society, the decline of traditions of working the land, increased mobility amongst populations and the erosion of rural identities (pp163-4). She laments the polarisation of Muslim and Coptic communities highlighting the things they have in common: language, music, the long tradition of sharing moulids (anniversaries of saints) and, most fundamentally, their Egyptian identity (pp155, 172).

Sandra Keriakos' contribution echoes the arguments that Mayeur-Jaouen presents. Keriakos examines the tradition of Marian apparitions in Egypt, in particular zeroing in on visions of the Virgin at Zeitun from 1968. This was an event that captured the imagination of Egyptians of both Muslim and Coptic affiliations. Keriakos notes that newspaper articles at the time recounted over 2400 eyewitness reports (p182), many of them telling of Muslims, in the unfamiliar environment of the church in Zeitun, imitating the litanies and gestures of the Copts in attendance (a phenomenon akin to that observed by Albera and Fliche at St Anthony's in Istanbul, where Muslim Turks sought to take the Eucharist, p114). Yet for all the hopes that Marian visions may highlight the commonalities that Egyptian Muslims and Christians share, Keriakos concludes that the divisions between distinct religious identities that have been promoted in the latter half of the twentieth century, and the political tensions they have exacerbated, have been too great to overcome (p198).

Political tensions are clearly at the forefront in Syria at present as well, and given news reports of massacres and atrocities occurring with such frequency it is hard to envisage a time when Syria's diverse ethnoreligious groups fraternized and mingled. Anna 


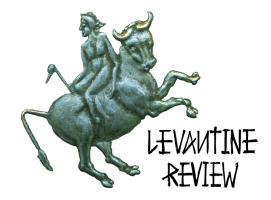

Poujeau records just that, however, in her chapter examining pluridenominational visits to Christian monasteries in Syria. Focusing in particular on the St Thecla monastery in Ma'lula, Poujeau highlights the fact that in existing on the territorial margins monasteries offer relief and respite from the strictures of Syrian society. In entering a monastery, everyone, whatever their confessional background, is regarded as being under the protection of the saint to whom the monastery is dedicated, thus allowing the expression of personal relationships with the saint, regardless of denominational claims (p216).

In summary, this volume is an extremely timely and welcome arrival, addressing as it does a yawning gap in the literature. Book-length studies of intercommunal devotional practices and interactions have been thin on the ground, the most notable of which, F. W. Hasluck's Christianity and Islam under the Sultans, was published all the way back in 1929. H. T. Norris' more recent Popular Sufism in Eastern Europe (2006) covered some similar territory to this volume, albeit limited to the prism of Sufi brotherhoods' dialogue with Christianity and without the wealth of detailed anthropological observation - the "thick description" — that Sharing Sacred Spaces includes.

The readership of this volume is likely to be considerable and varied. It will be of primary interest to anthropologists and ethnographers, while also offering valuable source material to students of comparative religion and offering insights for those investigating the societies and political systems of the Levant. General readers too will find accounts of festivals, rituals, apparitions and everyday devotional practices fascinating, although the book amounts to much more than just a collection of esoterica. In gathering an array of methodological perspectives and a range of different experiences, it brings to light a diversity of both commonalities and points of divergence in shared practices and spaces. Tellingly, it reveals that there is still much work to be done: as Bojan Baskar points out in the case of Bosnia, and Couroucli and Fliche in the case of Istanbul, there are still multitudinous instances of mixing and sharing that are yet to be observed, documented or analyzed. Being translated from the French, this title is also likely to bring a range of new voices to the attention of English readers and scholars.

Sharing Sacred Spaces will spark debate, perhaps controversy, and hopefully further research into points of contact between the monotheistic religions, and others. Collectively, the assembled papers illustrate that neither the naysayers who conceive of unbridgeable ethnoreligious divides, nor the idealists who seek to evoke a blissful history of interconfessional exchanges paint a complete picture. While we live in an era where, theoretically, religion and state are kept separate, it remains the case that religious practices are shaped by political forces, yet despite political impulses that seek to delineate and divide, devotional practices remain a vital space in which intercommunal mixing is able to occur. It is here, as Galia Valtchinova puts it (p87), that stakeholders negotiate local sociopolitical and supralocal constraints to achieve "equilibrium between earthly powers and divine order." 
* William Gourlay is a PhD candidate at the Centre for Islam and the Modern World at Monash University, Australia. His doctoral research is focused on notions of belonging and acceptance amongst the Kurdish and Alevi minorities in the Republic of Turkey. 